\title{
PSIKOLOGI HUMANISTIK: \\ Victor Frankl dan Ki Ageng Suryomentaram (KAS)
}

\author{
Atik Ma'rifatun Afifah \\ Prodi Psikologi Pendidikan Islam UIN Sunan Kalijaga \\ e-mail: atikafifah.elabd12@gmail.com
}

\begin{abstract}
Abstrak
Psikologi humanistik berbicara tentang potensi manusia untuk menyelesaikan masalah yang dihadapinya. Kebanyakan yang diketahui atau dianut sebagai psikologi humanistic terdapat dari barat, seperti Abraham Maslow (1908-1970) memaparkan tentang teori hirarki kebutuhan, Carl Roger (1902-1987) memaparkan teori client-centered therapy dan Victor Frankl (1905- 1997) memaparkan teori logoterapi. Sedangkan dari lokal terdapat KAS (Ki Ageng Suryamentaram) (1892-1962) memaparkan teori kawruh jiwa. Tulisan ini bertujuan untuk mengkomparasikan teori psikologi barat (Frankl) dan lokal (KAS). Penelitian ini termasuk jenis penelitian kepustakaan (library research) yang bersifat penelitian kualitatif. Peneliti menggunakan pendekatan hermeneutik (interpretasi gramatik) untuk menerjemahkan makna humanistik. Dari beberapa teori psikologi humanistic baik barat maupun lokal, mempunyai persamaan dan perbedaan. Meskipun barat lebih berkembang psikologi humanistic, Tak dapat dipungkiri bahwa lokal pun mempunyai konsep teori psikologi humanistic yang lebih dulu diaplikasikan.
\end{abstract}

Kata Kunci: psikologi, humanistik, Frankl (kebermaknaan), KAS (kawruh jiwa)

\begin{abstract}
Humanistic psychology talks about the potential of humans to solve the problems they face. Most of what is known or accepted as humanistic psychology comes from the West, such as Abraham Maslow (1908-1970), who describes the theory of the hierarchy of needs, Carl Roger (1902-1987) explained the theory of client-centered therapy and Victor Frankl (1905-1997) explained the theory of logotherapy. While the local KAS (Ki Ageng Suryamentaram) (18921962) explained the theory of the soul kawruh. This article will compare Western (Frankl) and local (KAS) psychological theories. This research belongs to the type of library research that is qualitative research. The researchers use the hermeneutic approach (grammatical interpretation) to translate humanistic meanings. From several theories of humanistic psychology, both western and local have similarities and differences. Although the West is more developed in humanistic psychology, it cannot be denied that the local also has the concept of humanistic psychology theory that was first used.
\end{abstract}

Keywords: psychology, humanism, Frankl (meaningfulness), KAS (kawruh soul) 


\section{PENDAHULUAN}

Secara umum, psikologi humanistik (Rahman, 2018, p. 257) muncul bersama dengan dua faktor, diantaranya: pertama, kejayaan yang diraih oleh psikologi behavior dan psikoanalis. Kedua, pada masa Renaissance sudah berkembang pemikiran atas psikologi humanistik. Dilihat dari akar kata, humanistic secara harfiah adalah humanista (Latin) dan mempunyai kemiripan kata dengan Humble (sahaja, sederhana) serta humus (tanah atau bumi). Kemudian menjadi kata homo (manusia) dan humanus dapat diartikan dengan sifat manusia atau membumi (Davies dalam Kholis ,2014). Teori humanistic lebih mengedepankan manusia bertanggung jawab terhadap dirinya sendiri (Corey dalam Zulfikar dkk, 2017). Sejalan dengan teori tersebut David dan Juli (dalam Nur Kholis, 2014) memparkan bahwa humanisme termasuk dalam gerakan psikologi dan sosiologi untuk menggali berbagai macam potensi dan kemampuan yang dimiliki individu dengan landasan nilai kemanusiaan, empati dan kompleksitas dari kehidupan individu.

Karakteristik humanistic dipaparkan oleh Glassman dan Hadad (Rahman, 2018, pp. 268-269) antara lain: pertama, psikologi humanistic lebih menekankan pada pengalaman subjektif individu. sehingga menghasilkan data secara objektif dengan metode intersubjective verification (mengumpulkan dan menganalisis data). Kedua, individu atau manusia mempunyai hak pilih dan kebebasan pengalaman. Ketiga, pengalaman manusia diyakini mempunyai makna dan nilai dalam perubahan manusia. Karakteristik humanistik mempunyai kemiripan dengan karakter humanistic yang digagas oleh KAS. Beliau lebih menekankan rasa pada diri manusia untuk mengetahui rasa orang lain.

Menurut pendekatan humanistik, manusia diibaratkan sebagai tumbuhan, yang mempunyai kecenderungan bawaan untuk tumbuh. Kecenderungan ini disebut dengan aktualisasi diri dan diasumsikan bahwa lingkungan orang mendukung pertumbuhannya, dan aktualisasi diri berjalan tanpa interferansi. Kaum humanis juga mengasumsikan bahwa manusia pun membutuhkan hal-hal tertentu untuk hidup, sepertihalnya tanaman membutuhkan sinar matahari, manusiapun membutuhkan perhatian positif. Menurut Roger perhatian positif ini adalah pengalaman menerima dari orang lain atau sekitarnya, yang menumbuhkan sikap untuk menghargai (M. Pomerant, 2014, pp. 376-377).

Seperti halnya penelitian yang dilakukan oleh Ratna tentang memahami watak Sama'an melalui keluarga gerilya, menggunakan pendekatan logterapi Frankl. Hal ini menunjukkan bahwa tokoh Sama'an dibawah belenggu penjajah Belanda mempunyai tekat yang kuat dan penderitaan menjadikan ia lebih bersemangat. Kekuatan spiritual yang digali juga perjalanan Sama'an juga menunjukkan nilai kemanusiaan. Sehingga pembaca turut merasakan perjuangan, penderitaan dan alur kehidupan dengan makna yang membuatnya lebih hidup dengan semangat. Dengan kata lain alur kehidupan akan lebih bisa dinikmati dengan individu yang membeikan makna (Razak, 2010). 
Kebermaknaan hidup juga dirasa oleh seorang narapidana (Marliana \& Maslihah, 2012) yang mendapatkan hukuman seumur hidup. Terlihat bahwa ia menemukan sumber kebermaknaan hidupnya dari nilai daya kreatif (mengikuti keliatan atau aktifitas yang sudah ditentukan oleh petugas, dan menjalani dengan baik. Aktifitas seperti pramuka, bercocok tanam, juga memberikan teladan bagi yang lainnya), nilai penghayatan diperoleh dari keyakinan bahwa Tuhan, keluarga, teman dan yang lainnya masih mengasihi dirinya. Kemudian nilai sikap ditindakan dengan menerima hukuman seumur hidupnya, dan menjalani kehidupan dengan bijak.

Paparan diatas menekankan bahwa makna hidup bisa dicapai atau diperoleh langsung dari diri individu sendiri, dengan menjalani, menerima serta menemukan makna ia hidup. Hal ini menunjukkan bahwa subyek pelaku menentukan arah hidupnya sendiri, dan dilihat dari sisi kemanusiaannya. Teori Frankl telah berkontribusi untuk individu agar ia menemukan makna hidupnya, dengan kata lain adanya motivasi bagi individu untuk tetap hidup, sebelum takdir kematian menjemputnya..

Dilihat dari sisi lokal, KAS sebagai tokoh psikologi humanistik telah menekankan rasa manusia yang ada pada dirinya sendiri untuk mengetahui dan memahami orang lain (Afif et al., 2012, p. 130). Dengan kata lain, ketika individu sudah mampu memahami rasa diri sendiri, ia pun dapat memahami rasa orang lain. Sebagai contoh ketika individu dicubit oleh orang lain itu terasa sakit, maka ketika individu mencubit orang lain juga akan sama mempunyai rasa sakit.

Menilik kembali teori humanistic lebih mengarah pada potensi dan kemampuan manusia dalam memecahkan masalah yang dihadapinya. Hal ini unik untuk diperbincangkan kembali antara teori barat dan lokal. Meskipun sama-sama membahas lebih berfokus pada kemanusiaan, kedua teori barat dan lokal pun mempunyai tokoh yang berlatar belakang berbeda. Sehingga memungkinkan penulis mengkaji lebih dalam teori humanistic tersebut.

\section{METODE}

Penelitian ini termasuk kualitatif (Qualitative Research) yaitu suatu penelitian yang ditunjukkan untuk mendeskripsikan dan menganalisis fenomena, persepsi, pemikiran orang secara individual maupun kelompok(Nana Syaodih Sukmadinata, 2008, p. 65). Termasuk dalam jenis penelitian kepustakaan (library research)(W. Creswell, 2016, p. 18). Pendekatan yang digunakan adalah hermenutik Upaya untuk menemukan makna dalam sebuah teks (Hardiman, 2018, p. 12). Sebagai modus analisis data untuk pemahaman manusia menafsirkan sesuatu makan dari teks (J. Moeleong, 2012, pp. 227-228). Metode yang digunakan adalah metode analisis isi (content Analysis) (Afifuddin, 2012, p. 165). 


\section{HASIL DAN PEMBAHASAN}

\section{Tokoh-tokoh psikologi humanistik}

1. Victor frankl (1905-1997)

Biografi Frankl

Frankl terlahir di Viena Australia, (Rahman, 2018, pp. 277-279) pada tanggal 26 Maret 1905. Beliau tertarik di bidang psikologi sejak memasuki sekolah menengah atas. Tokoh yang mempengaruhi pola pikir Frankl adalah Sigmund Freud, dengan melakukan korespondensi intensif. Dilanjut komunikasi intensif dengan Alfred Adler. Kemudian ide tentang kebermaknaan telah dibuat artikel oleh Frankl pada usia 20 tahun. Menginjak tahun 1928 - 1942 beliau menyibukkan diri dengan mengikuti aktivitas sosial, menekuni profesinya sebagai neurologi dan psikiater. Beliau juga membuka konseling di beberapa kota Eropa. Konseling ini dipengaruhi karena banyaknya kasus remaja yang bunuh diri akibat tidak menyelesaikan sekolah. Frankl menikahi Tilly Glosser pada tahun 1941. Pernikahan ini pun bahagia, sampai pada suatu kondisi yang mengharuskan Frankl dan keluarganya berpisah dan semuanya menjadi tahanan tentara NAZI di Auschwitz. Pengalaman Frankl di tahanan NAZI, membuahkan hasil teori kebermaknaan. Sehingga Frankl banyak bercerita mengenai pengalaman yang dialaminya hingga ia menemukan makna hidup.

\section{Kebermaknaan Hidup Frankl}

Kebermaknaan hidup atau biasa disebut dengan makna hidup, dalam psikologi dikenal dengan konsep atau teori logoterapi yang dibawakan oleh Vicktor E. Frankl. Orang memperjuangkan logoterapi untuk menemukan makna hidup sebagai motivator bagi dirinya sendiri (Diniari, 2017). Seseorang akan menemukan makna hidup konkrit didalam situasi yang konkrit atau disebut dengan situasi khusus (Fridayanti, 2013). Situasi yang dimaksud adalah penderitaan dan kematian (Mardhika, 2013). Konsep yang diusung oleh Frankl lebih dominan menekankan pada hati nurani manusia, sebagai bukti integritas manusia. Bagaimana manusia atau individu memainkan atau memerankan sisi intuitifnya dalam kehidupan yang bersifat kepribadian. Dengan kata lain logoterapi Frankl menunjukkan bahwa makna hidup seseorang terdapat dalam diri individu sendiri, yaitu dengan mencari dan menemukan makna yang terkandung didalamnya. Sehingga hidup dapat dikatan lebih berarti atau bermakna. Meskipun dalam situasi menderita sekalipun, akan tetap menemukna makna hidup yang sebenar-benarnya. Jadi makna hidup tidak selalu ditemukan ketika individu senang atau bahagia. Untuk menuju makna hidup yang sebenarnya bisa melalui fase penderitaan dan bahagia. Teori Frank menjelaskan makna dibagi menjadi 3 (tiga ) yaitu : makna hidup, makna cinta dan makna penderitaan. Dari berbagai makna tersebut terbentuklah kebermaknaan. (Frankl, 2019)

Pertama, Tujuan dan makna hidup menurut Frankl terdapat kandungan nilai didalamnya seperti: nilai kreatif, nilai penghayatan dan nilai bersikap (Lubis \& Maslihah, 2012).

a. Nilai kreatif/ daya cipta

Nilai kreatif individu ini terletak pada aktifitas yang dilakukan. Aktifitas yang menunjukkan produktifitas dari individu, yaitu mampu bertindak dan bersikap se- 
kreaatif mungkin dalam berkarya, bekerja, bertanggung jawab untuk menemukan makna yang terkandung didalamnya. Sehingga makna tersebut berharga dan berarti.

b. Nilai penghayatan

Nilai penghayatan ada pada situasi khusus individu. Individu yang belajar dari pengalaman, meyakini dan mempercayai kebenaran, kebajikan, kebaikan, bahkan keagaaman dari cinta kasihnya. Bagaimana individu atau seseorang dapat mencari dan menemukan makna hidupnya dari sebuah penghayatan baik kebahagiaan atau penderitaan.

c. Nilai bersikap

Nilai bersikap dapat ditemukan pada seseorang ketika ia mengalami sebuah situasi yang sekiranya tidak dapat diubah, maka ia akan mengambil sikap dari apa yang ada. Sehingga sikap ini akan terlahir dari seseorang untuk mendapatkan makna hidupnya sendiri (Diniari, 2017).

Kedua, makna cinta diraih oleh manusia untuk memahami manusia lain, didasari dengan cinta sehingga mengenali pribadi dengan dalam. cinta melahirkan pemahaman bagi manusia melalui karakter, keurangan, kelebihan potensi dari manusia yang ia cintai. Dalam hal ini, cinta juga diungkapkan dengan seks, mengungkapkan kebersamaan secara penting dari sebuah cinta.

Ketiga, makna penderitaan bisa manusia dapatkan melalui penderitaan.

Sebagaimana penderitaan yang tidak bisa dihindari oleh manusia. (Frankl, 2019).

Teori logoterapi Frankl mempunyai 2 (dua) macam teknik, antara lain: pertama, intensi paradoksal yaitu teknik yang digunakan melalui potensi fakta manusia, bahwa ketika manusia berada pada situasi takut, ketakutan yang ditakuti bisa saja terjadi. Kedua, dereflection yaitu kemampuan manusia dalam melakukan harapan yang berlebihan berujung pada kekecewaan(Rahman, 2018, p. 280).

\section{Ki ageng suryamentaram (KAS) ( 1892-1962) Biografi KAS}

Ki Ageng Suryamentaram (KAS) mempunyai nama kecil BRM (Bendara Raden Mas) Kudiarmaji. Beliau dilahirkan di kota Yogyakarta, pada tanggal 20 Mei 1892 dan masih keturunan raja. Karena ayah beliau adalah Sri Sultan Hamengku Buwono VII. KAS putra ke-55 dari 78 bersaudara. Sedangkan ibunya bernama BRA (Bendara Raden Ayu) Retnomandoyo putri dari patih Danureja VI. Dulunya beliau KAS sekolah di Srimangangi, masih area Yogyakarta, kemudian melanjutkan sekolah ke Klein Ambtenar. Beliau juga menyempatkan belajar Bahasa Belanda, Inggris dan Arab (Munif, 2017).

Semasa kecilnya ia habikan di lingkungan Kraton. Namun, pada usia ke 18 tahun beliau diangkat sebagai pangeran dengan gelar Bendoro Pangeran Haryo Suryamentaram. Kehidupan menjadi seorang pangeran membuatnya tidak merasa bahagia, kecewalah yang ia rasakan. Karena tidak suka dengan kekuasaan kraton. Hal ini 
membuatnya sering keluar dari lingkungan kraton, dengan pergi ke tempat-tempat yang mendatangkan ketenangan baginya (Nikmaturrahmah, 2016). Beliau merasa belum puas, karena apa yang ditemui atau dilihat selama ini bukanlah sosok orang yang sesuai dengan pandangannya dengan ungkapan "belum bertemu dengan orang "(seprana seprenen aku kok durung tau pethuk wong). Kemudian beliau pergi mengenakan pakaian layaknya pedagang dengan nama Notodongso, sebagai penjual batik di Cilacap. Namun berita kepergian beliau ke Cilacap telah diketahui oleh Sri Sultan Hamnegku Buwono VII. Sehingga ayahanda mengutus prajurit untuk mencari KAS, hingga akhirnya beliau ditemukan dan dijak pulang kembali ke Kraton Yogyakarta (Bonnef, 2012).

Pengalaman KAS berlanjut dengan peristiwa kakeknya patih Danurejo yang berhenti dari tugasnya, ibunya yang diceraikan oleh Sang raja berkelanjutan dengan istrinya yang meninggal dunia. Sehingga tepat pada pergantian tahta dari Sri Sultan Hamengku Buwono VII ke Sri Sultan Hamengku Buwono VIII, KAS meminta izin bahwa gelar pangerannya segera dicabut oleh sang raja. Dan Sang Raja pun memenuhi permintaannya. Kemudian beliau mendirikan "sarasehan selasa kliwon" kemudian mendirikan sekolah Taman Siswa bersama dengan $\mathrm{Ki}$ Hajar Dewantara (Muniroh, 2018, pp. 720-750). Singkat cerita, selama kurun waktu kurang lebih 40 tahun beliau mencari atau meneliti ilmu jiwa. Kemudia beliau wafat pada hari Ahad pon, 18 Maret 1962. belai dimakamkan di desa Kanggota, Pleret, Bantul, Yogyakarta (Nikmaturrohmah, 2016).

\section{Kawruh Jiwa KAS}

Pandangan KAS tentang manusia lebih dicondongkan oleh rasa (Prastetyo, 2012). Sering disebut dengan ukuran keempat, mempunyai arti empat tahapan, yaitu: pertama, pada ukuran pertama biasa disebut dengan bayi yang baru lahir. Bayi sudah bisa merasakan apa yang dia rasa seperti dingin, namun anggota badan belum berfungsi sebagaimana mestinya. Kedua, ukuran kedua sering disebut dengan anakanak, yaitu keinginan dan anggota tubuh sudah bisa bereaksi, namun belum paham akan hukum alam. Contohnya anak yang tertarik melihat api dan ingin memegangnya. Anak tersebut sudah berkeinginan dan memegang api, antara keinginan dan tindakan sudah bereaksi, namun belum paham bahwa api yang dipegang akan membahayakan dirinya. Ketiga, kehidupan orang beranjak dewasa, menegetahui maksud hati dicontohkan dengan anak yang tertarik dengan api, namun menyentuh dengan alat bantu, sehingga tidak berbahaya. Keempat, ukuran keempat disebut dengan kehidupan yang mempunyai perasaan terhadap benda-benda hidup. Dengan kata lain, lebih terhadap rasa. Bagaimana orang hidup mengahami keinginan dan perasaan orang lain.

Paparan ukuran keempat juga dibahas oleh Afif, tentang pandangan hidup mempunyai empat dimensi yaitu: tumbuhan, hewan, manusia, dan manusia yang bersinggungan dengan orang lain. Sehingga mengedepankan perasaan karena berhubungan dengan benda-benda hidup.

Melihat kembali teori humanistik Frankl dan KAS, keduanya memunyai persamaan yaitu menggali lebih dalam 
kemampuan dan potensi manusia dalam menyelesaikan masalah yang dihadapinya.

\section{Makna Hidup}

Teori kebermaknaan Frankl yang melibatkan 3 (tiga) pokok makna, yaitu makna hidup, cinta dan penderitaan. Sepertihalnya teori Frankl bahwa makna hidup mempunyai 3 (tiga) kriteria nilai yaitu: nilai daya cipta atau kreasi, penghayatan dan sikap. Nilai daya cipta atau kreasi ini pada pandangan KAS sepertihalnya hasrat birahi. Adanya hasrat birahi memunculkan pasangan untuk melestarikan kehidupannya dengan adanya anak. Dengan kata lain penciptaan anak yang dimulai dari hasrat birahi menghasilkan generasi penerus bagi pasangan. Ada yang melanjutkan hidupnya.

Nilai penghayatan, dilihat dari sisi individu, penghayatan dapat dilakukan dengan pengalaman yang berlangsung oleh individu sendiri. cara untuk menghayati diri pada pandangan KAS disebut dengan mulurmlungkret. Bagaimana individu mengharapkan sesuatu yang lebih. Sebagai contoh semisal individu mengharapkan niali kuliahnya A, namun ketika ia sudah mendapatkan nilai $\mathrm{A}$, merasa ada yang kurang, dengan menaikkan harapan nilai $\mathrm{A}+$ dan lulus dengan pujian. Hal ini dinamakan mulur, karena sesuatu yang sudah tercapai masih saja menginginkan hal lain diatasnya lagi dan lagi. Sedangkan mlungkret keinginan yang semakin diturunkan tingkatannya. Sebagai contoh individu yang tadinya menginginkan nilai $\mathrm{A}$, kemudian belum tercapai dan berharap nilai A-, jika nilai A- belum tercapai maka keinginannya pun menurun jadi nilai $\mathrm{B}+$. Hal ini menunjukkan bahwa antara teori Frankl tentang makna hidup melalui penghayatan dapat ditemukan juga dengan teori mulurmlungkret oleh KAS. Ada pula penjelasan KAS tenteng penghayatan individu, yaitu dengan mawas diri biasa disebut dengan "pengawikan pribadi"

Nilai sikap, dilihat dari individu bersikap akan dirinya sendiri. hal apa yang dilakukan seorang individu dalam menjalani situasi dan kondisi. Hal ini dalam pandnagan KAS disebut dengan 6 (enam) prinsip "sa". Jadi tindakan individu atau sikap yang diambil untuk menyikapi situasi dan kondisi yang sedang dialami menggunakan ungkapan sabutuhe, saperlune, sacukupe, sabenere, samesthine, sakepenake (seperlunya, secukupnya, sebenarnya, semestinya, dan sepantasnya). Hal ini jika ditindakan oleh individu akan membantu individu dalam menerima situasi dan kondisi yang dialami. Sebagai contoh ketika individu merasa lapar, ia akan bergegas makan, meski hanya dengan nasi dan lauk tempe. Makan yang mengenyangkan tidak harus menuruti nafsu, seperti ada soto, sate, rawon dll,. Hal ini menunjukkan bahwa lebih mengutamakan kebutuhan dari pada keinginan dengan apa adanya yang didepan mata, dan terjadi sekarang. .

\section{Makna cinta}

Makna cinta menurut Frankl(Victor E. Frankl, 2019, pp. 161-162) yaitu dengan cinta dapat membantu individu untuk memahami individu lainnya. Dengan berbagai karakter, kelebihan, kekurangan 
dan potensi yang dimilikinya. Makna cinta pun bisa dikatakan cinta tanpa syarat seperti pemikiran KAS (Suryomentaram, 1985b, p. 145), dengan cinta adanya hasrat birahi dan cinta kedua pasangan maka dapat melestarikan keturunan atau generasi penerus. Selain itu KAS juga membagi cinta menjadi tiga yaitu : harta benda, kedudukan dan kekuasaan (semat, drajat, kramat). Wujud cinta sering disebut dengan "sepi ing pamrih" hal ini menunjukkan bahwa cinta tanpa syarat. Ketika individu menemukan makna cinta, ia tidak akan terpaut dengan semat, drajat, dan kramat.

\section{Makna Penderitaan}

Penderitaan individu akan lebih bermakna jika disikapi dengan bijaksana. Menurut paparan Frankl dan pengalaman yang dialami pada saat di tahanan Nazi Auschwitz, bahwa penderitaan tidak semua akan sengsara. Bahkan dengan menderitapun individu mampu menemukan makna hidup dibalik penderitaan yang sedang melandanya. Tidak hanya terikat akan takdir kematianya, namun lebih ke bagaimana usaha individu menemukan makna hidup dibalik penderitaanya. Sikap menerima tanpa mengesampingkan usaha, justru membuat Frankl mampu bertahan hidup, sehingga ia sampai pada saat dibebaskan dari Tahanan. Namun, keluarganya yang lain telah meninggal dunia sebelum hari pembebasan diumumkan (Victor E. Frankl, 2019, pp. 162-167).

Senada dengan penderitaan, pengalaman KAS (Afif et al., 2012, p. 4)boleh dikategorikan dengan pengalaman yang cukup pahit. Bagaimana seorang pangeran yang hidupnya serba berkecukupan dan mewah, membuatnya belum menemukan manusia dan belum bahagia. Ia merasa yang ditemuinya bukanlah sesama manusia. Karena ia merasa masih ada yang tertindas di bawahnya, yaitu abdi ndalem yang gajinya hanya sedikit, namun merasa bahagia sudah mendapatkan lahan untuk bercocok tanam.

Penderitaan kerap kali berhubungan dengan susah, hal ini seperti yang dikemukakan oleh KAS bahwa dengan teori bungah-susah (Suryomentaram, 1985a, p. 1) adalah sepertihalnya siang -malam yang saling bergantian. Dengan kata lain, susah bahagia adalah paketan hidup bagi manusia. Tidak selamanya sedih maupaun bahagia. Sedih - bahagia silih berganti.

\begin{tabular}{|c|c|c|}
\hline Pembeda & $\begin{array}{l}\text { FRANKL } \\
\text { 1905- } 1997\end{array}$ & $\begin{array}{l}\text { KAS 1892- } \\
1962\end{array}$ \\
\hline Kelahiran & $\begin{array}{l}\text { Vienna } \\
\text { Australia, } \\
\text { 26 Maret } 1905\end{array}$ & $\begin{array}{l}\text { Yogyakarta, } \\
\text { Indonesia } \\
20 \quad \text { Mei } \\
1892\end{array}$ \\
\hline Keluarga & Berpendidikan & Kraton \\
\hline $\begin{array}{l}\text { Pendidika } \\
\text { n }\end{array}$ & $\begin{array}{l}\text { Universitas } \\
\text { Vienna }\end{array}$ & $\begin{array}{l}\text { - Sekolah } \\
\text { Kraton } \\
\text { Srimengan } \\
\text { ti } \\
\text { - Klien } \\
\text { Ambtenna } \\
\text { r }\end{array}$ \\
\hline Karya & $\begin{array}{l}\text { - On The } \\
\text { Psychology of } \\
\text { Philoshophica } \\
1 \text { Thought } \\
\text { - Psychoteraph } \\
\text { y and } \\
\text { Weltanschoun }\end{array}$ & $\begin{array}{l}\text { - Kitab } \\
\text { Kawruh } \\
\text { Jiwa }\end{array}$ \\
\hline
\end{tabular}




\begin{tabular}{|c|c|c|}
\hline & $\begin{array}{l}\mathrm{g} \\
\text { - Man's Search } \\
\text { for Meaning }\end{array}$ & \\
\hline Teori & $\begin{array}{l}\text { Teori } \\
\text { Kebermaknaan }\end{array}$ & $\begin{array}{l}\text { Teori } \\
\text { Kebahagiaa } \\
\text { n }\end{array}$ \\
\hline
\end{tabular}

\section{PENUTUP}

Paparan teori kebermaknaan Frankl jika diaplikasikan pada teori kebahagiaan KAS masih mempunyai keterkaitan. Bahwa kebermaknaan dapat dijapai apabila seseorang merasakan kebahagiaan. Dengan melihat kebermaknaan dan kebahagiaan mempunyai 3 ( tiga ) kriteria yaitu makna hidup, cinta dan penderitaan.

Berdasarkan penelitian yang dilakukan, maka peneliti memberikan saran untuk lebih mengaplikasikan lebih banyak teori lokal KAS untuk meneliti relevansi, implikasi teori yang dicetuskan oleh KAS pada penelitian yang ada di lokal/ daerah sendiri.

\section{DAFTAR PUSTAKA}

Afif, A., Atmosutidjo, K. P., Woodward, M., Bonneff, M., Saputro, M. E., Mawardi, B., Kushendrawati, S. M., Yoshimichi, S., Prihartanti, N., \& Ashimsa-Putra, H. S. (2012). Matahari Dari Mataram (Menyelami Spiritual Jawa Rasional Ki Ageng Suryomentaram ). Kepik.

Afifuddin. (2012). Metodologi Penelitian Kualitatif (2nd ed.). Pustaka Setia. Hardiman, F. B. (2018). Seni Memahami Hermeneutik Scheleimacher sampai Derrida (4th ed.). Kanisius.
J. Moeleong, L. (2012). Metodelogi Penelitian Kualitatif (30th ed.). Rosdakarya.

M. Pomerant, A. (2014). Psikologi Klinis. Pustaka Pelajar.

Marliana, S., \& Maslihah, S. (2012). Analisis Sumber-Sumber Kebermaknaan Hidup Narapidana Yang Menjalani Hukuman Seumur Hidup. Jurnal Psikologi, 11(1), 12. https://doi.org/10.14710/jpu.11.1.12 Muniroh, A. (2018). Kawruh Pamomong Ki Ageng Suryomentaram: PrinsipPrinsip Moral untuk

Mengoptimalkan Pendidikan Empati pada Anak. Proceedings of Annual Conference for Muslim Scholars, Series 2, 742-750.

Nana Syaodih Sukmadinata. (2008). Metode Penelitian Pendidikan. Rosdakarya. Nikmaturrohmah. (2016). Konsep manusia Ki Ageng Suryomentaram relevansi dengan pembentukan karakter sufistik. UIN Walisongo.

Rahman, A. A. (2018). Sejarah Psikologi:

Dari Klasik Hingga Modern (2nd ed.). Rajawali Pers.

Razak, R. R. A. (2010). Memahami Watak Sa'aman dalam Keluarga Gerilya: Satu Pendekatan Logoterapi Frankl. Akademia, 8.

Suryomentaram, K. A. (1985a). Ajaran Ajaran Ki Ageng Suryomentaram (Jilid 1) (G. Suryomentaram, K. O. Suastika, \& K. M. Atmosentono, Trans.). PT Inti Idayu Press.

Suryomentaram, K. A. (1985b). Ajaran Ajaran Ki Ageng Suryomentaram (Jilid 2) (G. Suryomentaram, K. O. 
Suastika, \& K. M. Atmosentono, Trans.). PT Inti Idayu Press.

Victor E. Frankl. (2019). Man's Search For Meaning (5th ed.). Noura Books.
W. Creswell, J. (2016). Research Desingn Pendekatan Metode Kualitatif, Kuantitatif dan Campuran (A.

Fawaid \& R. K. Pancasari, Trans.). Pustaka Pelajar. 